\title{
Task 7.1 - Strategic Planning
}

\author{
Semi-Annual Report \\ January 1 - June 30, 1995
}

RECEIVED

Allif 141997

By
Daniel J. Daly

OSTI

Work Performed Under Contract No: DE-FC21-93MC30097

For

U.S. Department of Energy

Office of Fossil Energy

Morgantown Energy Technology Center

P.O. Box 880

Morgantown, West Virginia 26507-0880

By

Energy and Environmental Research Center

University of North Dakota

P. O. Box 9018

Grand Forks, North Dakota 58202-9018

DISTRABUTHON OF THIS DOCUMENT IS UAumm

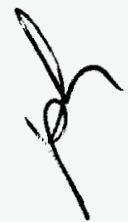

MASTER 


\section{Disclaimer}

This report was prepared as an account of work sponsored by an agency of the United States Government. Neither the United States Government nor any agency thereof, nor any of their employees, makes any warranty, express or implied, or assumes any legal liability or responsibility for the accuracy, completeness, or usefulness of any information, apparatus, product, or process disclosed, or represents that its use would not infringe privately owned rights. Reference herein to any specific commercial product, process, or service by trade name, trademark, manufacturer, or otherwise does not necessarily constitute or imply its endorsement, recommendation, or favoring by the United States Government or any agency thereof. The views and opinions of authors expressed herein do not necessarily state or reflect those of the United States Government or any agency thereof. 


\section{TASK 7.1 - STRATEGIC PLANNING}

Assessment of Alaskan opportunities for demonstrating new technologies for resource development and remote power generation was continued. The design and cost estimates for a demonstration plant to produce coal-water fuel (CWF) from low-sulfur Alaskan subbituminous coal were further reviewed to resolve issues of budget and plant capability. A preliminary evaluation was performed of potential cost and performance benefits to be derived from integrating the CWF plant with the demonstration of the AD Little/Cooper Bessimer CWF-fired diesel engine under the DOE Clean Coal Technology demonstration program. Tests on the Cooper Bessemer engine using Alaskan CWF prepared by the Energy \& Environmental Research Center (EERC) were recommended to determine engine performance at two levels of coal cleaning: physical cleaning to about $3 \%-4 \%$ ash or additional chemical cleaning to under $2 \%$ ash (dry basis).

Assistance was provided to graduate students in the Energy Engineering doctoral program at the University of North Dakota in reference to policy papers prepared by them on advanced power options, repowering strategies, and waste management. The information developed in these papers will be used by the EERC in its ongoing assessment of energy and environmental policy issues relating to its research and development program.

A presentation was prepared for the 1995 Community Economic Development and Infrastructure Conference in Mandan, North Dakota on May 11. The conference focused on opportunities for community-based economic development, including opportunities for by-products from regional energy production. Information was provided on by-products from the North Dakota lignite and gas industries, including coal ash, secondary products from the Great Plains coal gasification plant, sulfur from natural gas plants, advanced char products, and leonardite-(naturally occurring oxidized lignite) derived products.

Liaison was maintained with energy activities in East Central Europe following the meetings organized by the EERC in Prague, November, 1995, which included two DOE-sponsored workshops on least-cost power and ecological fuels and the following conference. Technical information was exchanged through Mr. Jiří Gavor of the Prague-based ENA Ltd. Under a consultancy agreement with the EERC, Mr. Gavor provided design information on the Czech Vresova Integrated Gas Combined Cycle (IGCC) project and in turn was kept informed on DOE Clean Coal Technology projects of interest in the Czech Republic.

No work was undertaken under Activity 2

Activities for the next quarter will be determined through discussions with EERC senior research staff. 


\section{M97002222}

InnW|

Report Number (14)DOE/MC/30097 = 5575

Jubl. Date (11) $\frac{1995}{D O E / F E, X F}$
sponsor Code (18)
JC Category (19) 